\title{
Cyril Elgood "A Medical History of Persia": A Critique
}

\author{
Touraj Nayernouri, $\mathrm{MD}^{{ }^{*}}$ \\ 'Academy of Medical Sciences of Islamic Republic of Iran, Tehran, Iran
}

\section{Introduction}

Cyril Lloyd Elgood (1893-1970) was physician to the British legation in Tehran from 1925-1931. His interest in Iranian medicine led to the writing of 'A Medical History of Persia and the Eastern Caliphate' in 1948 (published 1951) which is the only comprehensive medical history of Iran in English, from ancient pre-Islamic times until 1932, and has been a valuable text to the researchers of Iranian medical history. ${ }^{1}$

In this essay, I have only attempted a critique of the first two chapters of the book which deal with pre-Islamic medicine in Iran, but have not mentioned the post-Islamic sections as most of which is beyond the scope of my knowledge.

The reason that I have chosen the pre-Islamic section of the book is that most Iranian students of history of medicine, when writing of ancient Iranian medicine, treat Cyril Elgood's book as their main reference together with translations of Al-Qifti and Ibn-abi Usaibia.

This is unfortunate as Elgood's first two chapters are replete with incorrect historical facts as well as unfounded stories without proper references.

\section{A Medical History of Persia}

Many pages of these two chapters deal with the history of the Achamenids, extracted from Herodotus, Xenophon and Ctesias; and that of the Sassanians, from Edward Gibbon, an $18^{\text {th }}$ century English historian and Arthur Christensen (1875-1945), the Danish Ironologist. Most of this history is not medically relevant.

Within these historical accounts, however, there are several incorrect statements which I will point out successively.

1: On page 37, Elgood quotes Gibbon that during the reign of Ardeshir Papakan, there was a Magi by the name of Ardai-Viraf who in a soporific dream journeyed to the nether world, visited heaven and hell and on waking, related his experiences of that world to the Zoroastrian believers.

In the first place, Ardai-viraf Nameh is probably a late Sassanian story which had its final redaction during the $9^{\text {th }}$ or $10^{\text {th }}$ centuries. $^{2}$

If there was a Zoroastrian priest during the time of Ardeshir I Papakan, his name may have been Tansar, who is mentioned in a late Sassanian text, 'Nameh Tansar', revised during the reign of Khosro I Anoushiravan (reign 531-579 CE).

There was, however, a Zoroastrian priest by the name of Kartir, who gained prominence from the time of Shapur I (reign- 241-272 CE) and had a stone inscription of his achievements and his journey to heaven at Naqsh-e-Rajab. ${ }^{3}$

2: Again on page 37, it is mentioned that Ardeshir's administration was directed by the council of Zoroastrian priesthood and "all worship, except that of the Zoroastrian faith, was forbidden." In fact, both Ardeshir and his son Shapur I were very tolerant of all religions, both of Christianity and Manichaeism as well as Buddhism. Shapur I had welcomed Mani to his court and permitted him to spread his teachings throughout his empire, and Mani wrote his book, 'Shaburagan', in Pahlavi language specifically for Shapur. ${ }^{4}$

Furthermore, after Shapur defeated the Roman Emperor, Valerian in $256 \mathrm{CE}$, he established 'Weh-Antioch-Shapur' (Gondeshapur) as a royal city and settled many Roman captives there as well as in other parts of southern Iran and appointed Demetrianus, the Christian Bishop of Antioch to Gondeshapur to minister to the Roman deportees. ${ }^{5}$ The Nestorian Christian Church of the East flourished during the Parthian and the early Sassanian rule, as the Christians fled to the East due to the persecution of the Christians in the Roman Empire before the time of Constantine (ruled 306-377 CE) who declared Christianity as the religion of the Roman Empire.

Throughout the Sassanian epoch, the Catholicus of the Nestorian Church had their Seat at Selucia-Ctesiphon and many of them had close ties with the King. ${ }^{5}$

Many Christian physicians were employed at the Sassanian courts including Marthas of Martyropolis, ${ }^{6}$ Oribanus, Stephanus, Sergius of Res Ayna, ${ }^{7}$ Tribanus and Qashway as personal Physicians to Khosro I Anoushiravan. ${ }^{8}$

And finally, there was Gabriel of Sinjar, a Nestorian physician as a Drustbed and chief physician at the court 
of Khosro II Parviz (reign 590-628 C.E.) who had cured Khosro II's second wife, the Aramaic Christian, Shirin, of her barrenness and therefore, had great influence at court. ${ }^{9} 10$

It is curious that Elgood states incorrectly (pages 54-55) that "during the reign of Nushiravan...Jibrail, the Iranian Durustpat...cured Shirin, the favorite wife of Nushirvan of her sterility."

3: On page 39, it is stated that during the reign of Shapur I: "The Avestan language, the original tongue which Zoroaster and the people of his time wrote and spoke, was the language of Iran until the Medes and Persians replaced it with Pahlavi."

The several factual and historical errors in this one sentence needs no elaboration since the Medes and the Persians came at least 800 years before the time of Sassanid Shapur I and Pahlavi was the language of the Sassanians and not of the Achamenids.

4: Again on page 5, he states that Zarathustra or Zoroaster was "born in the town of Urumieh, a city in the north-west corner of modern Persia." It is well established that Zarathustra was born and preached in north-East Iran in the region of Chorasmia (Khwarazmia). ${ }^{11}$ It was the Magis who had acquired Zoroastrianism from the priests of Eastern Iran during the early centuries of the Christian era, that is in later Parthian and early Sassanian times who attempted to transfer Zoroaster to North-Western Iran, renamed certain locales after Avestan places and insisted that the Aryan abode was in Azerbaijan and that Zoroaster was in fact a Magi. ${ }^{12}$

5: On page 6, Elgood reiterates the oft quoted factoid perpetrated by late Sassanian Mobeds that the written Avesta was destroyed by Alexander the Great when he set fire to Persepolis and its archives. Modern scholarship has clearly demonstrated that the Avesta had remained an oral tradition and was never committed to writing until the mid Sassanian era when a special alphabet was devised to record the traditional pronunciation of its language. .3-16 $^{-1}$

As far as medicine and its practice is concerned, Elgood relies heavily on late Zoroastrian literature, much of which postdates the demise of the Sassanian empire. Again, I shall list successively many of his factual errors in this regard.

1: On page 4, he mentions Assyrian surgical methods and prescriptions of drugs and refers to the inscriptions of the 'Stele of Hammurabi'. The codes of Hammurabi were the laws of ancient Mesopotamia dealing with civil contract which were written in Akkadian cuneiform on a stone stele and clay tablets during the reign of the Babylonian king, Hammurabi, in the $18^{\text {th }}$ century B.C.E. The only reference to medical practice in these laws (Laws 215-218) deal with the payments to the physicians for their services. No methods of treatment or prescriptions are mentioned. ${ }^{17}$

2: Again on page 5, he states that "...an homeopathic theory underlies all later Persian medicine." This is an unfounded statement as there is no evidence that the early Zoroastrian medicine was based on a 'homeopathic' principle and Elgood gives no corroborative reference.

3: On page 12, Elgood writes, "Medical training must have taken place in many centers. The largest schools were probably those at Ray, Hamedan and Persepolis. At these three cities, there must have been hospitals." Such a statement is totally groundless as there are no references to such medical centers and is purely speculation on his part.

4: There are several statements listed below, for which there are neither corroborative evidence nor references:

a) Page 19- "It is not too bold to go even further and claim that the Persians taught the Greeks the elements of that system of medicine, which has been known ever since as Greek medicine."

b) Page 19- "The doctrine of the humours is taught in unmistakable terms in the holy books of the Hindus, which were composed prior to 2000 BCE." Which Hindu Books written prior to $2000 \mathrm{BCE}$ is he referring to which describe the doctrine of the humours?

5: On page 20, there is reference to the Bundahishn which is claimed to have shared in building the humoral theory. This book is a very late Sassanian or even partly post-Sassanian manuscript which deals with the creation of the world and which in some parts, compares humanity as a microcosm reflecting the cosmic macrocosm. There is no reference to the humoral theory or medical practice in this book, which postdates Hippocrates and Galen by several centuries. ${ }^{18} \mathrm{On}$ the same page, there is a comparison between the Bundahishn statement that "the marrow of the body is like liquid metal within the Earth" with the Hippocratic statement that "the marrow is hot and damp.' The logic of such a comparison seems beyond my comprehension!

There is also on page 21 a paragraph that "To the Iranians, then, can probably be given the credit of introducing to the world a philosophical concept upon which the Greek system of anatomy, physiology and pathology were ultimately based." The evidence for such a leap of faith is totally unfounded.

At the beginning of chapter II (page 34), Elgood describes a myth of the three Persian Magis who visit the baby Jesus Christ who was born in Bethlehem and that these three Persian-Priests assisted in his birth. This myth is a very late elaboration of the popular Nativity scenes performed at Christmas and is also the subject of many paintings.

The Gospel according to Mathew is the only Gospel in which the "wise men from the East" are mentioned. There are no Kings, no Magis and there is no mention of the number of these wise men who went to Jerusalem and enquired "where is he that is born to be King of The Jews?" 19 There is no mention in any Christian writing that these "Three Persian-Priest Physicians" assisted in the birth of Jesus Christ. In fact, they arrived several days after 
the birth.

In conclusion, in this article, I have attempted to review and criticize the first two chapters of Cyril Elgood's 'A Medical History of Persia and the Eastern Caliphate' which was published in 1951. As this text is so often quoted verbatim by students of Ancient Iranian Medicine, I thought it appropriate to criticize and point out the various historical and factual inaccuracies contained in the sections related to pre-Islamic medicine.

I hope that this essay might be useful to those students and that in the future, such blatantly misguided quotations from this book will not be repeated. My aim has been to emphasize and encourage researchers of history to check and verify the sources and references of the text which they quote.

\section{Conflict of Interest Disclosures}

None.

\section{Ethical Statement}

Not applicable.

\section{References}

1. Elgood C. A Medical History of Persia and the Eastern Caliphate. Cambridge: Cambridge University Press; 2010.

2. Gingoux P. Arda Wiraz. Encyclopedia Iranica.

3. Prods Oktor Skjarevo. KARTIR. Encyclopedia Iranica.

4. Werner Sundermann. 'Mani'. Encyclopedia Iranica.
5. Wood P. The Chronicle of Seert: Oxford Early Christian Studies. UK: Oxford University Press; 2013.

6. Blockley RC. Doctors as Diplomats in the Sixth Century C.E. Vol. 2. Florilegium; 1980. p 89-100 .

7. Gul Russel. Greece x. Greek Medicine in Persia. Encyclopedia Iranica.

8. Renink GJ. Theology and Medicine in Jundishapur: Cultural Change in the Nestorian School Tradition. Leuven-ParisDudley MA: Peeters Publishers: 2003.

9. Christensen A. Iran at the time of Sassanians. Farsi translation by Rashid Yassemi. Tehran: Donyaye Ketab; 1993; 634-5.

10. Richter-Bernburg L. Gondešapur ii. History and Medical School. Encyclopedia Iranica.

11. Gnoli G. Avestan Geography. Encyclopedia Iranica.

12. Zarghamee R. Discovering Cyrus. Washington DC: Mage Publishers; 2013. p. 152-8.

13. Kellens J, Avesta I. Survey of the History and Contents of the Book. Encyclopedia Iranica. p. 35-44.

14. Boyce M. Zoroastrians, Their Religious Beliefs and Practices. London: Routledge and Kegan Paul; 1979. p. 17.

15. Avestan. Oxford: Faculty of Oriental Studies. Available from: https://www.orinst.ox.ac.uk/avestan. Accessed November 27, 2019.

16. Amouzegar J. Zaban, Farhang, Ostooreh (in Farsi). Tehran: Moin Publishers; 2007. p. 61.

17. Hooker R. Mesopotamia: The Code of Hammurabi. Translated by King LW. USA: Washington State University; 1996.

18. Neil MacKensie D. Bundahišn. Encyclopedia Iranica.

19. Gospel according to Mathew 2. The Authorized Version of the English Bible known as 'The King James' Version'. 